\title{
Morphological and molecular description of Myxobolus batalhensis n. sp. (Myxozoa, Myxosporea), a liver and ovary parasite of Salminus hilarii in Brazil
}

\author{
Diego Henrique Mirandola Dias Vieira ${ }^{1}$ Gema Alama-Bermejo ${ }^{2,3}$. \\ Jerri Lee Bartholomew ${ }^{2}$ - Vanessa Doro Abdallah ${ }^{4} \cdot$ Rodney Kozlowiski de Azevedo $^{4}$
}

Received: 28 April 2017 / Accepted: 4 October 2017 /Published online: 14 October 2017

(C) Springer-Verlag GmbH Germany 2017

\begin{abstract}
Plasmodia containing myxospores belonging to the genus Myxobolus Bütschli, 1882 were found in the ovaries and liver of Salminus hilarii. Despite its economic value, this fish host has no previous reports of myxozoan infections. Herein, we describe Myxobolus batalhensis n. sp. using morphological and ultrastructural data, as well as histological and SSU rDNA molecular data. The mature myxospores were elongated, measuring in average $15.2 \pm 0.8 \mu \mathrm{m}$ in length, $8.4 \pm 0.4 \mu \mathrm{m}$ in width, and $5.1 \pm 0.2 \mu \mathrm{m}$ in thickness. Polar capsules were elongated and measured $5.3 \pm 0.3 \mu \mathrm{m}$ in length and $2.8 \pm 0.3 \mu \mathrm{m}$ in width. Polar filaments had 6-9 coils. Histopathological analysis showed coagulation necrosis associated with cell lysis as a response of the host cell to the parasite in the ovaries. No inflammatory reaction was observed in the liver, although the presence of the plasmodia caused changes in tissue structure. The phylogenetic analysis of South American myxobolid species showed M. batalhensis n. sp. as sister species of Myxobolus aureus. This is the first report of a myxozoan species parasitizing $S$. hilarii and the first myxozoan species described in the Batalha river.
\end{abstract}

Diego Henrique Mirandola Dias Vieira

diegovieira.50@gmail.com

1 Department of Parasitology, Universidade Estadual Paulista "Júlio de Mesquita Filho" - UNESP, Botucatu, São Paulo, Brazil

2 Department of Microbiology, Oregon State University, Corvallis, OR, USA

3 Center for Applied Research and Technology Transference in Marine Resources Almirante Storni (CIMAS-CCT CONICET) \& ESCiMar, National University of Comahue, San Antonio Oeste, Argentina

4 Department of Environmental Sciences, Universidade do Sagrado Coração - USC, Bauru, São Paulo, Brazil
Keywords Bryconidae $\cdot$ Histopathology $\cdot$ Myxobolidae Phylogeny · SSU rDNA · Ultrastructure

\section{Introduction}

Myxozoans are microscopic parasitic cnidarians of fish (Okamura et al. 2015). The occurrence of myxozoan parasites has been extensively studied in aquaculture due to their pathogenic potential (Feist and Longshaw 2006). Myxozoans can induce significant mortalities in wild and farmed fishes, leading to major economic losses (Naldoni et al. 2009; Morsy et al. 2012; Gómez et al. 2014). Among the problems related to myxozoan infections are reduced respiratory capacity (Adriano et al. 2005), longitudinal compression of the body (Longshaw et al. 2003), degenerative cardiomyopathy (Yokoyama et al. 2005), and intestinal necrosis (AlvarezPellitero et al. 2008).

Among myxozoans, the class Myxosporea Bütschli, 1881 represents more than 2200 species, with approximately 910 species belonging to the genus Myxobolus Bütschli, 1882 (Lom and Dykova 2006). Of the known Myxobolus species, approximately 60 have been described from Brazil (Eiras et al. 2014). Species have been described from various tissues and organs, including gills (Adriano et al. 2009; Azevedo et al. 2014), liver (Carriero et al. 2013), spine (Longshaw et al. 2003), and heart (Ye et al. 2014). Reports of myxozoans in Brazil parasitizing the gonads include Henneguya amazonica Rocha et al., 1992 from the testes of Hoplosternum littorale Hancock, 1828 (Torres et al. 1994), Myxobolus lutzi Aragão, 1919 parasitizing the testes of Poecilia vivipara Bloch and Schneider, 1801 (Aragão 1919), and Myxobolus testicularis Tajdari et al., 2005 parasitizing the testes of Hemiodopsis microlepis Kner, 1859 (Tajdari et al. 2005). 
The species Salminus hilarii Valenciennes, 1850 is of great importance for commercial and sport fishing (Andrade et al. 2004). The tabarana or dourado-branco is a characid fish of the subfamily Salminae with a wide distribution in Brazilian river basins (Godoy 1975). To date, there is no record of myxozoans parasitizing $S$. hilarii, but three myxozoan species have been described from other members of the genus, Salminus brasiliensis (Cuvier, 1816), namely Myxobolus salminus Adriano et al., 2009 and Myxobolus pantanalis Carriero et al., 2013 both in gills, and Myxobolus aureus Carriero et al., 2013 in liver (Adriano et al. 2009; Carriero et al. 2013).

During a parasitological survey of $S$. hilarii, plasmodia containing myxospores morphologically consistent with Myxobolus were observed in ovaries and liver. The main goal of this study was to identify and compare the myxobolid species using morphological and molecular data as well as to evaluate their phylogenetic relationship with other representatives of the Myxobolidae family. In addition, we provided ultrastructural and histological details of the plasmodia, comparing the pathologies caused by the parasite in different organs.

\section{Materials and methods}

\section{Fish collection}

From March 2014 to June 2015, specimens of $S$. hilarii $(n=8$; 27-30.2 cm total length, 491.55-698.40 g; 6 females/2 males) were collected in Reginópolis, Batalha river $\left(21^{\circ} 52^{\prime} 33.0^{\prime \prime} \mathrm{S}\right.$, $49^{\circ} 14^{\prime} 19.9^{\prime \prime}$ W), São Paulo, Brazil. Fish were collected using gill nets and euthanized by neural pithing immediately after capture. All fish captured had a minimum size of $20 \mathrm{~cm}$, which is the first stage of sexual maturation (Andrade et al. 2004). Sex was determined by external morphology of the fish and confirmed by observation of the gonads after dissection. Fish were examined within $24 \mathrm{~h}$ of capture, and fresh smears of gills, stomach, intestine, heart, liver, gonad, bone marrow, kidney, swim bladder, and gall bladder were evaluated under a differential interference contrast microscope (Leica DMLB 5000, Leica Microsystems, Wetzlar, Germany) at $\times 1000$ magnification. Samples of liver and ovaries infected with myxozoans were collected for further molecular and morphological analysis.

\section{Morphological examination}

Morphological measurements of fresh spores followed the recommendations of Lom and Arthur (1989): spore length, spore width, spore thickness, polar capsule length, polar capsule width, and number of turns of the polar filament. Measurements of 30 spores from livers and 30 spores from ovaries from the five infected fish were taken fresh from digital images at $\times 1000$ magnification, under light microscopy with Leica software application suite LAS V3.8 (Leica Microsystems).

For transmission electron microscopy (TEM), one oocyte from ovaries and one small piece of liver containing plasmodia were fixed in Karnovsky's solution at $4{ }^{\circ} \mathrm{C}$ for $10 \mathrm{~h}$. After being rinsed overnight in the fixative at $4{ }^{\circ} \mathrm{C}$, tissue was post-fixed in $2 \%$ osmium tetroxide for $3 \mathrm{~h}$ at $4{ }^{\circ} \mathrm{C}$. Subsequently, the tissue was immersed in $0.5 \%$ uranyl acetate in distilled water for $2 \mathrm{~h}$. Tissue fragments were dehydrated through an ascending ethanol series followed by propylene oxide and embedded in Epon resin. Semi-thin sections were stained with methylene blue-Azure II and observed under differential interference contrast microscope. Ultra-thin sections were double-stained with aqueous uranyl acetate and lead citrate and observed under a JEOL 100CXII (TEM) operated at $60 \mathrm{kV}$.

For histological analysis, both infected and uninfected oocytes were fixed with Karnovsky's solution, and dehydration was initiated afterwards in increasing concentrations of alcohol ( $3 \times$ into $70 \%$ for $2 \mathrm{~h}$ and $95 \%$ for $4 \mathrm{~h}$ ). The material underwent a resin-alcohol mixture for $12 \mathrm{~h}$. Finally, the tissue was embedded in resin (HistoResin, Leica, Germany). The $3 \mu \mathrm{m}$ sections were stained with hematoxylin-eosin, then examined under light microscope.

\section{Molecular analysis}

Two myxozoan plasmodia, one from ovaries and one from liver, were preserved in absolute ethanol. DNA isolation was carried out in accordance with the animal tissue protocol of the DNeasy Blood \& Tissue Kit (Qiagen, Valencia, CA, USA). Partial SSU rDNA gene was amplified using a combination of PCR and nested PCR with general eukaryotic and myxozoan primers (Table 1). Amplifications were performed on a Peltier 200 Thermocycler (MJ Research, Watertown, MA), with initial denaturation at $94{ }^{\circ} \mathrm{C}$ for $3 \mathrm{~min}$, followed by 28 or $35 \mathrm{cy}-$ cles for primary PCR, and 35 cycles for nested PCR of $94{ }^{\circ} \mathrm{C}$ for $40 \mathrm{~s}, 55^{\circ} \mathrm{C}$ for $40 \mathrm{~s}, 72^{\circ} \mathrm{C}$ for $2 \mathrm{~min}$, and a final extension at $72{ }^{\circ} \mathrm{C}$ for $10 \mathrm{~min}$. PCR reactions were performed in $10 \mu \mathrm{L}$ total volume, containing 0.625 U GoTaq ${ }^{\circledR}$ Flexi PCR polymerase (Promega, San Luis Obispo, California, USA), $2 \mu \mathrm{L}$ of $5 \times$ Flexi PCR Buffer, $0.75 \mathrm{mM}$ of $\mathrm{MgCl}_{2}$ (Promega), $0.5 \mu \mathrm{L}$ of Rediload Dye (Invitrogen, Carlsbad, CA), $0.2 \mathrm{mM}$ from each dNTP, $0.5 \mu \mathrm{M}$ from each primer, and $10 \mathrm{ng}$ of template DNA. Nested PCR was performed in a $25-\mu \mathrm{L}$ volume and with $150 \mathrm{ng}$ of PCR product as template. PCR products were electrophoresed through $1 \%$ agarose gel in TAE buffer stained with $1 \%$ SYBRsafe (Invitrogen) alongside a 1-kb DNA ladder (Invitrogen) and visualized under UV-light. After checking for the presence of the expected size DNA amplicons, PCR products were cleaned up using ExoSAP-IT® (Affymetrix, Santa 
Table 1 SSU rDNA primers used in this study, sequence, amplicon size, PCR rounds, and reference

\begin{tabular}{lllll}
\hline Primer & Sequence 5'-3' & Amplicon size (bp) & PCR round & Author \\
\hline ERIB1 & ACCTGGTTGATCCTGCCAG & $\approx 1900$ & 1st & Barta et al. (1997) \\
ERIB10 & CTTCCGCAGGTTCACCTACGG & & Barta et al. (1997) \\
MyxGP2F & WTGGATAACCGTGGGAAA & $\approx 800$ & Nested & Kent et al. (1998) \\
MyxospecR & GGTTCNCDGRGGGMCCAAC & & & Fiala (2006) \\
Act1R & AATTTCACCTCTCGCTGCCA & $\approx 900$ & 1st (paired with ERIB1) & Hallet and Diamant (2001) \\
MyxGen4F & GTGCCTTGAATAAATCAGAG & $\approx 900$ & 1st (paired with ERIB10) & Diamant et al. (2004) \\
\hline
\end{tabular}

Clara, CA, USA). The PCR products were sequenced using PCR and nested PCR primers on a ABI 3730 capillary sequence machine (Applied Biosystems, Foster City, CA, USA) at the Oregon State University Center for Genome Research and Biocomputing.

The sequences obtained for each sample were assembled and edited using BioEdit v. 7.0.9 (Hall 2011) to obtain longer consensus sequences of around 1700-1900 bp. The consensus sequences were aligned to all known sequences from South American myxobolids reported from freshwater fish using the ClustalW algorithm (Larkin et al. 2007) and default settings in Geneious version 7.1.3 (Kearse et al. 2012). The malacosporean, Buddenbrockia allmani (KJ150260), was used as outgroup, for being of an ancestral clade related to Myxosporea. The nucleotide substitution model was selected from 82 potential evolutionary models based on the Akaike information criterion using jModel Test 2.1 (Posada 2008), which identified the general time reversible model with gamma distribution and invariable rates $(\mathrm{GTR}+\mathrm{I}+\mathrm{G})$ as the model of best fit. The nucleotide frequencies were $\mathrm{A}=0.2369$, $\mathrm{C}=0.1935, \mathrm{G}=0.2930$, and $T=0.2766$ with estimated nucleotide substitution rates of $\mathrm{AC}=1.3171$, $\mathrm{AG}=4.0876, \mathrm{AT}=1.7304, \mathrm{CG}=0.7000, \mathrm{CT}=4.5812$, and $\mathrm{GT}=1.0000$. The gamma distribution was 0.3190 .

Bayesian inference (BI) and maximum likelihood (ML) methods were used for phylogenetic analysis. MrBayes 3.1.2 (Ronquist \& Huelsenbeck 2003) was used to perform the BI using Markov Chain Monte Carlo (MCMC) tree searches as implemented. Two parallel runs of four simultaneous MCMC searches for 5 million generations each were performed. The trees were used by MrBayes to estimate the posterior probability of each node in our phylogenetic reconstruction. Tracer v1.6 (Rambaut et al. 2014) was used to check the stationarity of all parameters sampled by the chains. PhyML 3.1 (Guindon et al. 2010) software was used to perform ML analysis, using bootstrap confidence calculated with 1000 replications and GTR + I + G evolutionary model. The trees obtained were visualized using Figtree 1.4.3 (Rambaut 2012) and edited using Adobe PhotoShop (Adobe Systems Inc., CA, USA). An alignment containing only trimmed sequences of
Myxobolus spp. parasites of bryconid fishes from South America was used to produce a distance matrix.

\section{Results}

The morphology of the myxospores found in the ovaries and liver of $S$. hilarii corresponded with the genus Myxobolus according to Fiala et al. (2015). Myxozoan parasites were recovered from five of six females examined, and each positive fish had simultaneous infections in both the ovaries and liver. No myxozoans were present in either of the two male fish collected. As a consensus of morphological, ultrastructural, and molecular data, a new Myxobolus species is described.

\section{Molecular and phylogenetic analysis}

A 1901-bp fragment of the SSU rDNA gene was amplified from spores infecting the ovaries and a 1768-bp fragment of the SSU rDNA gene from spores infecting the liver of $S$. hilarii. Both sequences were identical. The BLAST search using our newly generated SSU rDNA sequences did not match with other myxozoan sequences available in GenBank. The closest species was $M$. aureus, which showed a $93.6 \%$ similarity with a difference of 53 nucleotides (Table 2).

Phylogenetic analysis demonstrated the South American myxozoans that parasitize bryconid fishes clustered into two polyphyletic groups, one falling within a clade of gill infecting myxozoans and another that falls within a cluster of other viscera infecting myxozoans. Based on this data, M. batalhensis n. sp. appears as a sister species of $M$. aureus (Fig. 1).

Description of Myxobolus batalhensis n. sp.

Phylum Cnidaria Hatschek, 1888

Unranked subphylum Myxozoa Grassé, 1970

Class Myxosporea Bütschli, 1881

Order Bivalvulida Shulman, 1959

Family Myxobolidae Thélohan, 1892

Genus Myxobolus Bütschli, 1882

Myxobolus batalhensis n. sp. 
Table 2 Similarity in SSU rDNA sequences of Myxobolus species parasites of Bryconid fishes from South America. Lower triangle shows actual nucleotide difference, while the upper triangle shows the percentage of nucleotide difference

\begin{tabular}{|c|c|c|c|c|c|c|c|c|c|c|c|}
\hline & Host isolate & 1 & 2 & 3 & 4 & 5 & 6 & 7 & 8 & 9 & 10 \\
\hline 1 & $\begin{array}{l}\text { Myxobolus batalhensis } \mathrm{n} \text {. } \\
\text { sp. (Gonad) }\end{array}$ & & 0.01 & 6.4 & 26.4 & 25 & 25 & 13.7 & 13.3 & 14.2 & 14.6 \\
\hline 2 & $\begin{array}{l}\text { Myxobolus batalhensis } \mathrm{n} \text {. } \\
\text { sp. (Liver) }\end{array}$ & 1 & & 6.4 & 26.4 & 25 & 25 & 13.7 & 13.3 & 14.2 & 14.6 \\
\hline 3 & Myxobolus aureus & 53 & 53 & & 25.7 & 25.4 & 25.2 & 15.1 & 14.1 & 14.6 & 15.9 \\
\hline 4 & Myxobolus pantanalis & 224 & 223 & 218 & & 13.7 & 13.3 & 27.5 & 26.9 & 28.1 & 27.3 \\
\hline 5 & Myxobolus oliveirai & 213 & 212 & 216 & 115 & & 3 & 25.9 & 25 & 26.1 & 24.8 \\
\hline 6 & Myxobolus filamentum & 213 & 212 & 214 & 112 & 25 & & 26 & 25.1 & 26.1 & 24.7 \\
\hline 7 & Myxobolus piraputangae & 114 & 113 & 125 & 233 & 220 & 221 & & 10.2 & 8.2 & 6.3 \\
\hline 8 & Myxobolus umidus & 110 & 110 & 116 & 228 & 212 & 213 & 84 & & 10 & 16.7 \\
\hline 9 & Myxobolus hilarii & 118 & 117 & 120 & 238 & 222 & 222 & 67 & 82 & & 16.9 \\
\hline 10 & $\begin{array}{l}\text { Myxobolus } \\
\quad \text { macroplasmodialis }\end{array}$ & 122 & 121 & 132 & 231 & 211 & 210 & 135 & 139 & 140 & \\
\hline
\end{tabular}

Myxospores Myxospores: $(n=30$ fresh spores from ovaries and $n=30$ fresh spores from liver). Elongate and ellipsoidal spores (Fig. 2a, b). Measurements for spores found in ovary were $15.2 \pm 0.8(14.0-15.4) \mu \mathrm{m}$ spore length, $8.5 \pm 0.5$ (8.0 8.7) $\mu \mathrm{m}$ spore width, and $5.2 \pm 0.3(5.0-5.2) \mu \mathrm{m}$ spore thickness. Polar capsules elongate and pyriform, $5.2 \pm 0.3(5.0-5.5)$ $\mu \mathrm{m}$ in length and $2.8 \pm 0.2(2.6-3.0) \mu \mathrm{m}$ in width. Polar filament allocated in 6-9 coils. Measurements for spores found in liver were $15.3 \pm 0.9(14.0-15.5) \mu \mathrm{m}$ spore length, $8.3 \pm 0.3(8.1-8.5) \mu \mathrm{m}$ spore width, and $5.0 \pm 0.1(4.9-5.0)$ $\mu \mathrm{m}$ spore thickness. Polar capsules elongate and pyriform, $5.4 \pm 0.1(5.3-5.5) \mu \mathrm{m}$ in length and $2.8 \pm 0.1(2.8-2.9) \mu \mathrm{m}$

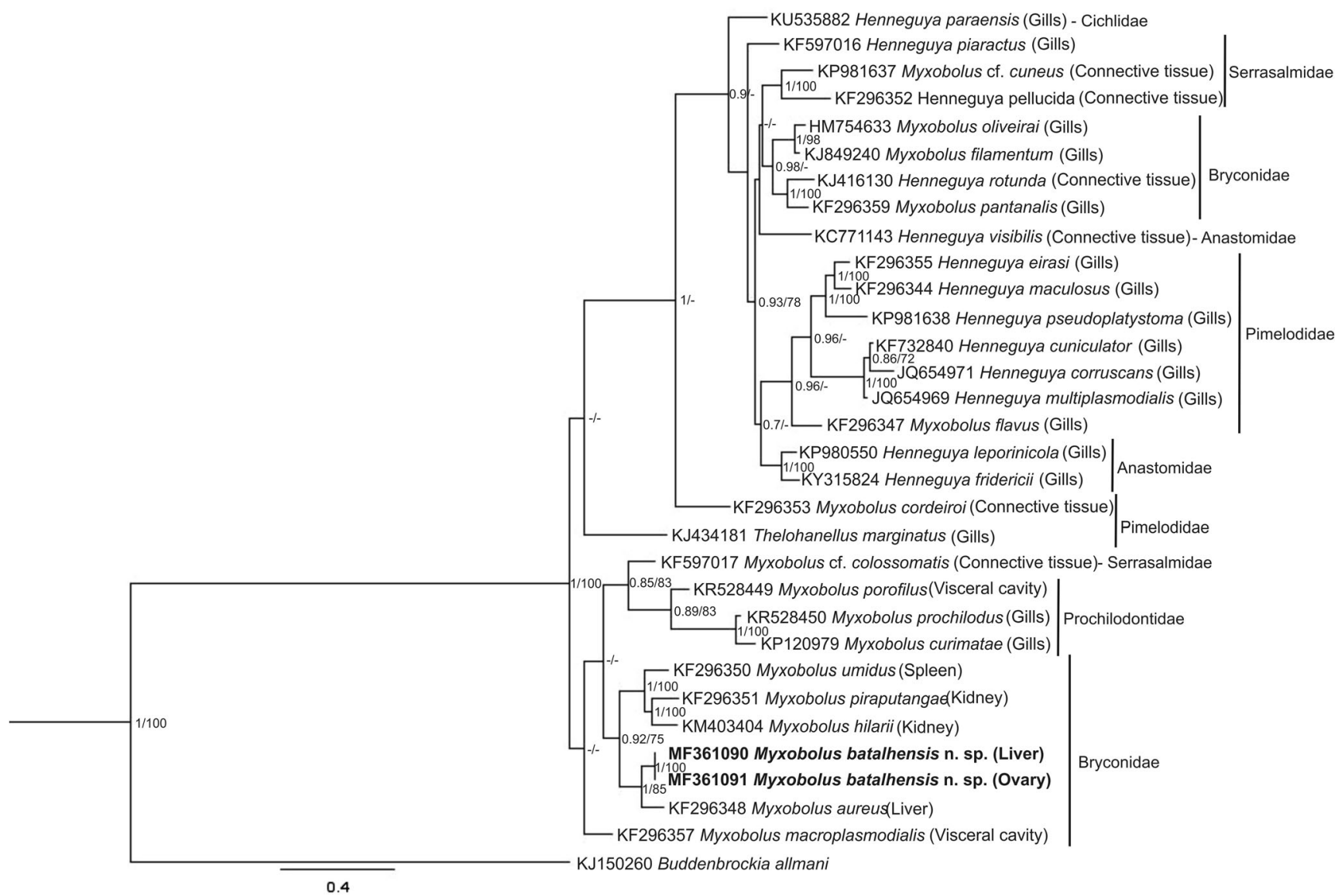

Fig. 1 Maximum likelihood phylogenetic tree based on partial SSU rDNA sequences showing the position of Myxobolus batalhensis n. sp. among other myxobolids from South America. Numbers at the nodes represent Bayesian posterior probability and bootstrap values (BI/ML) gaining more than 0.7 posterior probability (BI) and $70 \%$ support (ML). Values lower than $0.7 / 70$ are represented by dashes, and in parenthesis, the infected organ. Scale bar is given under the tree 
Fig. 2 a-c Images of Myxobolus batalhensis $\mathrm{n}$. sp. spores in Salminus hilarii. a Mature spores found in ovary. b Mature spores found in liver. $\mathbf{c}$ Schematic illustration of spore

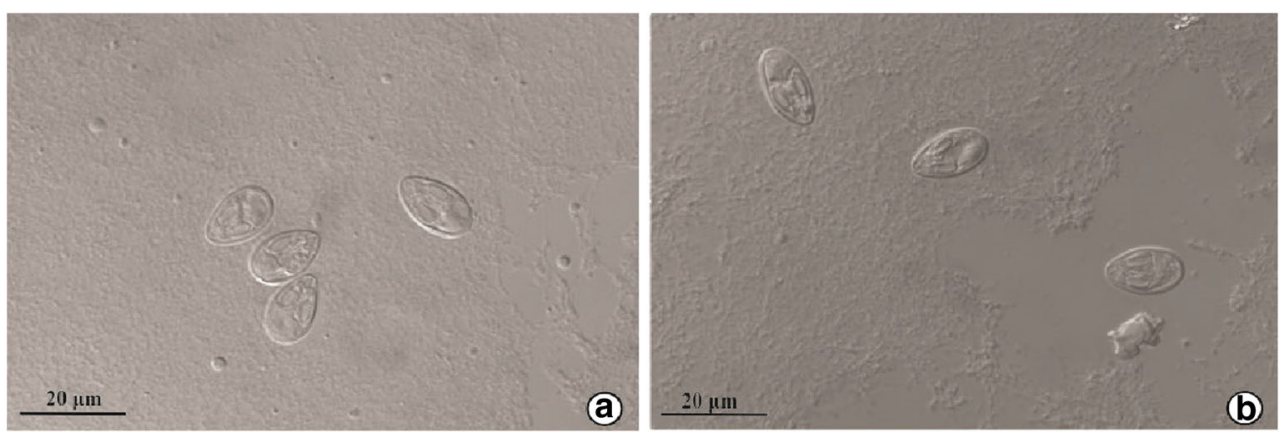

in width. Polar filament allocated in 6-9 coils. Binucleate sporoplasm. The presence of two valves, meeting at sutural line. Polar capsules had anterior ends close to each other (Fig. 2c).

Plasmodia Plasmodia is whitish and round, approximately $0.25 \mathrm{~cm}$ in the liver (Fig. 3a) and approximately $0.5 \mathrm{~cm}$ diameter in ovaries (Fig. 3b, c).

\section{Taxonomic summary}

Type host Salminus hilarii Valenciennes, 1850

Type locality Batalha river $\left(22^{\circ} 38^{\prime} 36.6^{\prime \prime} \mathrm{S}, 49^{\circ} 11^{\prime} 49.4^{\prime \prime} \mathrm{W}\right)$, Reginópolis, São Paulo, Brazil

Site of infection Ovaries and liver

Prevalence $62.5 \%(5 / 8)$ in S. hilarii ovaries and liver

Etymology The species name is derived from the name of the river where the hosts were collected.

Material deposited Glycerogelatin glass slides containing myxospores were deposited in the collection of the Museum of Zoology, "Adão José Cardoso," Institute of Biology, University of Campinas (UNICAMP), São Paulo, Brazil (ZUEC-MYX 66 and ZUEC-MYX 67).

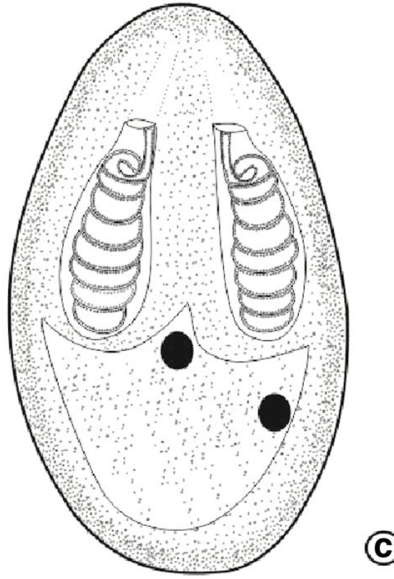

Sequence data The 1901- and 1768-bp of SSU rDNA sequences obtained from infected S. hilarii ovaries (GenBank Acc. Num. MF361090) and liver (GenBank Acc. Num. MF361091) respectively.

\section{Remarks}

The morphology of M. batalhensis n. sp. was compared to other Myxobolus spp. reported from bryconid fishes (Table 3). Among the 11 species included in the comparison, only Myxobolus paranensis Bonetto and Pignalberi, 1965 has been reported from gonads, although from a different host (S. maxillosus). Moreover, the ranges of spore body length and number of turns in the polar filament coil were considerably more variable than the values reported here for M. batalhensis $\mathrm{n}$. sp., while the polar capsules differed in length.

Among Myxobolus species that infect fish of the family Bryconidae, the most similar to M. batalhensis n. sp. was Myxobolus umidus Carriero et al., 2013. However, they differed in spore thickness, number of polar filament coils, and site of infection (spleen vs. ovary/liver). Comparably, M. aureus infects the liver of another Salminus sp., S. brasiliensis, although M. batalhensis n. sp. spores are considerably larger. The minimum and maximum number of coils of the polar filament also differed between these two species, 
Fig. 3 a-f Images of infected organs and histological analysis of uninfected and infected oocytes by Myxobolus batalhensis $\mathrm{n}$. sp. a The presence of plasmodia (arrows) in the liver of Salminus hilarii. Bar $1 \mathrm{~cm}$. b Whitish infected oocyte (arrow). Bar $1 \mathrm{~cm}$. c Oocyte infected (arrow), with the presence of numerous plasmodia inside. Bar $1 \mathrm{~cm}$. d Example of uninfected primary oocyte $(\mathrm{PO})$ with the ooplasm (O), follicular epithelium (FE), and zona pellucida (ZP) intact (staining: HE). e Mass of spores filling an infected oocyte and probably impacting on their reproductive function by the coagulation necrosis associated with cell lysis $(\mathrm{CN})$ (staining: HE). f Histological comparison of mature oocyte in the ovarian stroma (OS) infected and healthy primary oocytes (PO). Infected oocyte often showed disruption of the zona pellucida (PD) and released a large number of spores (S) in ovarian interstitium (OI). The absence of follicular epithelium associated with cell lysis (staining: HE)

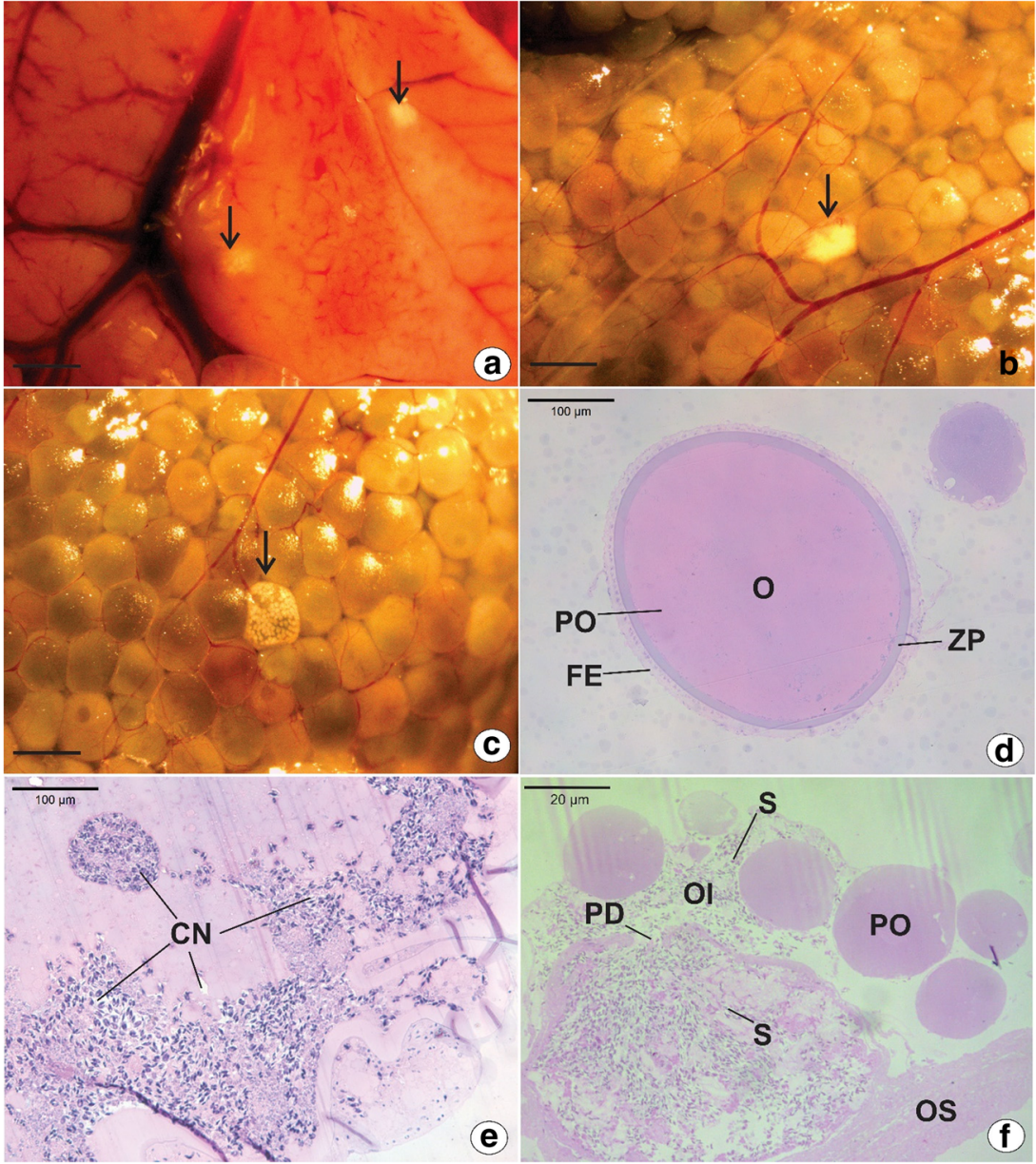

being 6-9 for $M$. batalhensis $\mathrm{n}$. sp. and 7-8 for $M$. aureus (Table 3).

When compared with Myxobolus species that parasitize gonads of fish from Brazil, $M$. batalhensis n. sp. showed to be larger than $M$. lutzi $(10 \mu \mathrm{m})$ and $M$. testicularis $(8.6 \pm 0.5 \mu \mathrm{m})$. Both species parasitize the testes and have not been reported from ovaries.

\section{Histological analysis}

The plasmodia found in the liver were in average $0.25 \mathrm{~cm}$ in diameter and contained numerous mature spores (Fig. 3a). Macroscopically, the presence of plasmodia in the liver disrupted hepatic tissue structure but did not illicit a marked immune response.

The plasmodia found in the ovaries could completely fill an oocyte (Fig. 3b, c). When infected and healthy primary oocytes were compared, external and internal structural differences were observed. In the uninfected primary oocytes, it was possible to observe the follicular epithelium, zona pellucida, and ooplasm (Fig. 3d). However, in infected oocytes, it was not possible to observe any of the normal architecture, such as teca cells, zona radiata, and even the nucleus, due to the degradation caused by the parasite. Coagulation necrosis associated with cell lysis as a response to the developing parasite resulted in reduction of the functional area of the oocyte (Fig. $3 e)$. Spores were observed occupying the entire oocyte cytoplasm, displacing the nucleus of the oocyte. It was also observed that the zona pellucida of follicles ruptured and the absence of the follicular epithelium, releasing spores into the ovarian interstitium (Fig. 3f).

\section{Ultrastructural analysis}

Ultrastructural observations were based on spores found in oocytes and liver of $S$. hilarii. Spores consisted of two polar capsules, two enveloping valve cells, and one binucleate sporoplasm with numerous sporoplasmosomes (Fig. 4a, b). The sporoplasm contained abundant endoplasmic reticulum and numerous mitochondria, and the polar capsules consisted of an inner lucent layer and a thin outer dense layer (Fig. 4c). Inside the fully developed polar capsule, six to nine turns of the polar filament were observed. The polar filament was arranged in a granular matrix (Fig. 4c). Along the suture line, spore valves (Fig. 4d) formed deep invaginations (Fig. 4e, f). The opening for polar filament discharge was located in the 
Table 3 Comparison of Myxobolus batalhensis n. sp. to other Myxobolus species parasites of Bryconid fishes from South America

\begin{tabular}{|c|c|c|c|c|c|c|c|c|c|}
\hline Species & Spore length & $\begin{array}{l}\text { Spore } \\
\text { width }\end{array}$ & Thickness & LPC & WPC & $\mathrm{CPF}$ & $\begin{array}{l}\text { Site of } \\
\text { infection }\end{array}$ & Host & Study \\
\hline \multirow[t]{2}{*}{ M. batalhensis $\mathrm{n} . \mathrm{sp}$. } & $\begin{array}{l}15.2 \pm 0.8 \\
\quad(14.0-15.4)\end{array}$ & $\begin{array}{l}8.5 \pm 0.5 \\
\quad(8.0-8.7)\end{array}$ & $\begin{array}{l}5.2 \pm 0.3 \\
\quad(5.0-5.2)\end{array}$ & $\begin{array}{l}5.2 \pm 0.3 \\
\quad(5.0-5.5)\end{array}$ & $\begin{array}{l}2.8 \pm 0.2 \\
\quad(2.6-3.0)\end{array}$ & $6-9$ & Ovary & $\begin{array}{r}\text { Salminus } \\
\text { hilarii }\end{array}$ & This study \\
\hline & $\begin{array}{l}15.3 \pm 0.9 \\
\quad(14.0-15.5)\end{array}$ & $\begin{array}{l}8.3 \pm 0.3 \\
\quad(8.1-8.5)\end{array}$ & $\begin{array}{l}5.0 \pm 0.1 \\
\quad(4.9-5.0)\end{array}$ & $\begin{array}{l}5.4 \pm 0.1 \\
\quad(5.3-5.5)\end{array}$ & $\begin{array}{l}2.8 \pm 0.1 \\
\quad(2.8-2.9)\end{array}$ & $6-9$ & Liver & $\begin{array}{r}\text { Salminus } \\
\text { hilarii }\end{array}$ & This study \\
\hline M. aureus & $12.6 \pm 0.5$ & $8.3 \pm 0.3$ & $5.5 \pm 0.3$ & $5.7 \pm 0.3$ & $2.9 \pm 0.2$ & $7-8$ & Liver & $\begin{array}{l}\text { Salminus } \\
\quad \text { brasiliensis }\end{array}$ & $\begin{array}{l}\text { Carriero et al. } \\
\text { (2013) }\end{array}$ \\
\hline M. paranensis & $12-15$ & $7-8$ & - & $6-7$ & 2.5 & $8-11$ & $\begin{array}{l}\text { Testes, } \\
\text { ovary }\end{array}$ & $\begin{array}{l}\text { Salminus } \\
\quad \text { maxillosus }\end{array}$ & $\begin{array}{l}\text { Bonetto and } \\
\text { Pignalberi } \\
\text { (1965) }\end{array}$ \\
\hline M. hilarii & $11.5 \pm 0.8$ & $11.0 \pm 0.7$ & $7.6 \pm 1.0$ & $6.5 \pm 0.4$ & $4.0 \pm 0.2$ & $5-7$ & Kidney & Brycon hilarii & $\begin{array}{l}\text { Capodifoglio } \\
\text { et al. (2016) }\end{array}$ \\
\hline M. brycon & $6.9(6.5-7.2)$ & $\begin{array}{l}4.2 \\
\quad(3.9-4.8)\end{array}$ & $\begin{array}{l}2.5 \\
\quad(1.9-2.8)\end{array}$ & $\begin{array}{l}4.2 \\
\quad(3.8-4.7)\end{array}$ & $\begin{array}{l}1.9 \\
(1.7-2.5)\end{array}$ & $8-9$ & Gill & Brycon hilarii & $\begin{array}{l}\text { Azevedo et al. } \\
\text { (2011) }\end{array}$ \\
\hline M. oliveirai & $11.2 \pm 0.4$ & $7.4 \pm 0.5$ & $4.6 \pm 0.6$ & $5.6 \pm 0.2$ & $2.3 \pm 0.2$ & $6-8$ & Gill & Brycon hilarii & $\begin{array}{l}\text { Milanin et al. } \\
\quad(2010)\end{array}$ \\
\hline M. piraputangae & $10.1 \pm 0.5$ & $8.7 \pm 0.5$ & $6.7 \pm 0.3$ & $5.2 \pm 0.4$ & $3.0 \pm 0.3$ & $4-5$ & Kidney & Brycon hilarii & $\begin{array}{l}\text { Carriero et al. } \\
\text { (2013) }\end{array}$ \\
\hline M. umidus & $13.5 \pm 0.7$ & $7.8 \pm 0.4$ & $7.7 \pm 0.1$ & $5.1 \pm 0.4$ & $2.7 \pm 0.3$ & $4-5$ & Spleen & Brycon hilarii & $\begin{array}{l}\text { Carriero et al. } \\
\text { (2013) }\end{array}$ \\
\hline M. filamentum & $9.0 \pm 0.3$ & $6.2 \pm 0.4$ & $5.3 \pm 0.3$ & $4.7 \pm 0.3$ & $1.7 \pm 0.1$ & $10-11$ & Gill & $\begin{array}{l}\text { Brycon } \\
\quad \text { orthotaenia }\end{array}$ & $\begin{array}{l}\text { Naldoni et al. } \\
\quad(2015)\end{array}$ \\
\hline M. macroplasmodialis & $11(10.5-12)$ & $8.5(8-9)$ & $5.2(5-5.5)$ & $4.5(4-5)$ & $2.8(2-3)$ & 6 & $\begin{array}{l}\text { Abdominal } \\
\text { cavity }\end{array}$ & $\begin{array}{l}\text { Salminus } \\
\quad \text { maxillosus }\end{array}$ & $\begin{array}{l}\text { Molnár et al. } \\
\text { (1998) }\end{array}$ \\
\hline M. pantanalis & $9.3 \pm 0.4$ & $6.5 \pm 0.4$ & - & $4.2 \pm 0.5$ & $2.0 \pm 0.1$ & $4-5$ & Gill & $\begin{array}{l}\text { Salminus } \\
\quad \text { brasiliensis }\end{array}$ & $\begin{array}{l}\text { Carriero et al. } \\
\quad(2013)\end{array}$ \\
\hline M. salminus & $10.1 \pm 0.4$ & $6.1 \pm 0.4$ & $5.0 \pm 0.6$ & $4.6 \pm 0.2$ & $1.7 \pm 0.1$ & $7-8$ & Gill & $\begin{array}{l}\text { Salminus } \\
\quad \text { brasiliensis }\end{array}$ & $\begin{array}{l}\text { Adriano et al. } \\
\text { (2009) }\end{array}$ \\
\hline
\end{tabular}

All measurements are in $\mu \mathrm{m}$

$L P C$ length of polar capsule, WPC width of polar capsule, $C P F$ number of coils of polar filament, - no data

shell valve next to the apical end of spore where the polar filament was invaginated (Fig. 4f).

\section{Discussion}

Spore morphology combined with molecular data, host organ, and specificity is essential data for the determination of a new myxozoan species (Kato et al. 2017). In accordance with this taxonomic strategy, we described a new species of Myxobolus, a liver and ovary parasite of a commercially important fish species in Brazil.

Phylogenetic analysis performed here supports previous work that suggests host family and tissue tropism which are strong phylogenetic signals for myxobolid species parasitizing families of South American fishes (Eszterbauer 2004; Fiala 2006; Carriero et al. 2013; Capodifoglio et al. 2016). We obtained a well-supported phylogenetic tree demonstrating two polyphyletic groups, one composed of species of Myxobolus and another composed primarily of species of Henneguya. In the Myxobolus group, M. aureus, a liver parasite, appeared as a sister group of $M$. batalhensis $\mathrm{n}$. sp. The sequence divergence between both species (Table 2) exceeded values typically associated with interspecific variability (Cech et al. 2012), supporting the claim that M. batalhensis n. sp. and M. aureus are not conspecific. Myxobolus spp. that parasitize fish of the Bryconidae family, such as M. umidus in spleen of Brycon hilarii Valenciennes, 1850, Myxobolus hilarii Capodifoglio et al. 2016 in kidney of B. hilarii and Myxobolus piraputangae Carriero et al., 2013 in kidney of $B$. hilarii also clustered in the myxobolid clade. A subclade formed by Myxobolus macroplasmodialis Molnár et al., 1998, a parasite of the visceral cavity of a bryconid fish, appeared as the clade basal species.

Similar host and tissue tropism was observed in the clade composed primarily of Henneguya spp. The species were divided into two major groups, with one group consisting mainly of Henneguya spp. parasitizing fish of the family Pimelodidae Eigenmann, 1918 and another group composed mainly of Henneguya spp. infecting various species of the 
Fig. 4 a-f Transmission electron microscopy images of spores of Myxobolus batalhensis n. sp. in the ovary and liver of Salminus hilarii. a A transverse section showing two polar capsules (PC). Notice the deep invagination of the shell valve suture (ISV). $\mathbf{b}$ Section through a spore with a binucleate $(\mathrm{N})$ sporoplasm containing numerous sporoplasmosomes (SPS). c Section of two spores showing sporoplasmosomes (SPS) in the sporoplasm, mitochondria (M), and large polar capsules (PC) containing coiled polar filament (arrow, 6-9 coils). Notice the outer electron-dense layer (OL), an inner electron-lucent layer (IL), and the granular matrix (GM) of the polar capsules. d Section of spore showing numerous mitochondria $(\mathrm{M})$ and two polar capsules with the polar filament (arrows); valve (V). e Notice the deep invagination of the shell valve suture (ISV), the binucleate $(\mathrm{N})$ sporoplasm, and the large polar capsule (PC) in this section. $\mathbf{f}$ Notice the invagination of the shell valve (ISV) and the opening of the polar capsule (OPC)
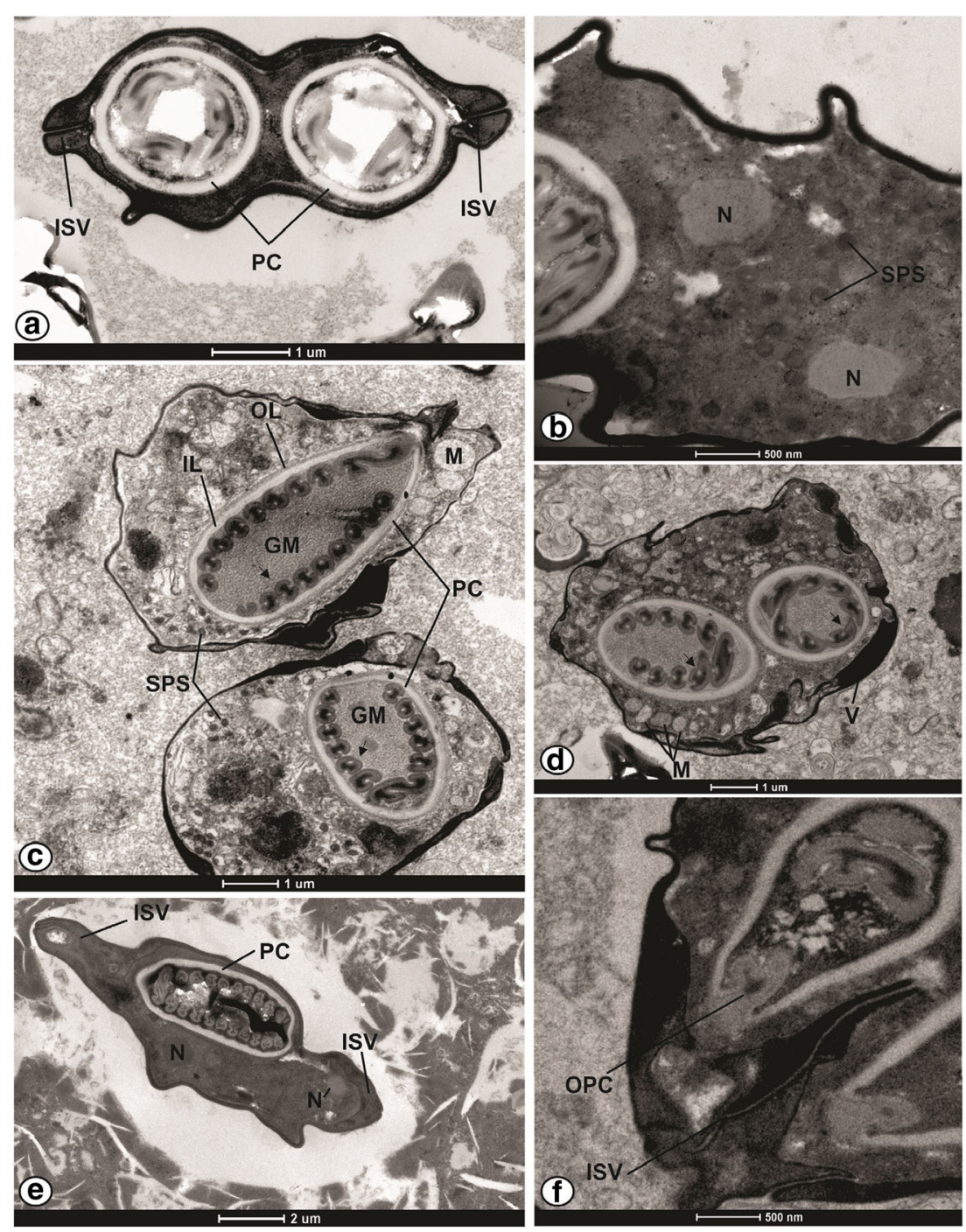

families Bryconidae and Serrasalmidae Bleeker, 1859. Carriero et al. (2013) and Capodifoglio et al. (2016) suggested myxobolids parasitizing members of the Bryconidae had a polyphyletic origin, with phylogenetic placement largely influenced by host species, consistent with trends reported here. Comparatively, Molnár (1994) suggested tissue affinity is an important character for specific assignment. In the current study, we noted that myxozoan parasites of fish from South America tend to form two main groups: one of them that infects gills and their connective tissue, while the other group are parasites of the body and visceral organs.

While the number of males analyzed in this study was low, Myxobolus batalhensis $\mathrm{n}$. $\mathrm{sp}$. were only observed in female fish. This may indicate a preference of the parasite for ovaries and that parasites found in the liver could be an aberrant occurrence, or that physiological and behavioral factors related to host sex may be involved in the dynamics of infection.

According to the latest reviews of Myxobolus spp. (Eiras et al. 2005, 2014), this genus demonstrates a wide range of tissue tropism and host specificity. Data suggest that myxozoans have serious pathological potential when encysted on reproductive tissues (Swearer and Robertson 1999; Sitjà-Bobadilla and Alvarez-Pellitero 1993) both in wild and cultured fish (Moran et al. 1999; Palenzuela 2006). Sitjà-Bobadilla (2009) emphasized the importance of controlling myxozoans in aquaculture, especially those species that cause damage to host gonads, as these can affect the host reproductive capacity by means of parasitic castration through disintegration of the infected oocyte membrane (Grankoto et al. 2001). In general, studies on ovarian infections of myxozoans focused on the ultrastructural features (Okaeme et al. 1988; Obiekezie and Okaeme 1990), but a combination of ultrastructural and histological analyses are needed for the elucidation of their pathological effects. In our study, we observed that M. batalhensis $\mathrm{n}$. $\mathrm{sp}$. infection lead to membrane destruction of affected oocytes and vacuolar degeneration. The structure of these infected oocytes was altered by the 
massive presence and proliferation of spores, most likely affecting their normal development and fertilization.

Several Myxobolus spp. have been described infecting liver of South American fishes (Molnár and Békési 1993; Adriano et al. 2006) including M. aureus infecting the liver of S. brasiliensis (Carriero et al. 2013). In none of these cases did the parasites cause serious damage to the host. Although M. batalhensis $\mathrm{n}$. sp. caused histopathological changes in the liver, the host response in the fish examined was minimal. This may reflect when they were sampled and thus should be further studied to fully understand the pathologic potential of this parasite.

Given the spore morphology, the morphometric data and SSU rDNA gene sequence obtained in the present study, we reported the new species Myxobolus batalhensis n. sp. This finding contributes to our knowledge of the biodiversity of myxozoans in Brazil. To the best of our knowledge, M. batalhensis $\mathrm{n}$. sp. is the first record of a myxozoan species parasitizing S. hilarii and the first myxozoan species described in the Batalha river.

Acknowledgments We are grateful to Fundação de Amparo à Pesquisa do Estado de São Paulo (FAPESP) (Process: 2013/25623-0, 2014/128620, 2015/01361-2, and 2015/24901-2), Czech Science Foundation (1428784P) and Consellería de Educación, Cultura y Deporte, Valencia, Spain (APOSTD/2013/087). We would like to thank Reinaldo José da Silva, Marianna Vaz Rodrigues, and Maria Isabel Müller for their support during this research.

\section{Compliance with ethical standards}

Ethical approval All applicable international, national, and/or institutional guidelines for the care and use of animals were followed.

Conflict of interest The authors declare that they have no conflict of interest.

\section{References}

Adriano EA, Arana S, Cordeiro NS (2005) Histology, ultrastructure and prevalence of Henneguya piaractus (Myxosporea) infecting the gills of Piaractus mesopotamicus (Characidae) cultivated in Brazil. Dis Aquat Org 64(3):229-235. https://doi.org/10.3354/dao064229

Adriano EA, Arana S, Cordeiro NS (2006) Myxobolus cuneus n. sp. (Myxosporea) infecting the connective tissue of Piaractus mesopotamicus (Pisces: Characidae) in Brazil: histopathology and ultrastructure. Parasite 13(2):137-142. https://doi.org/10.1051/ parasite/2006132137

Adriano EA, Arana S, Carriero MM, Naldoni J, Ceccarelli PS, Maia AAM (2009) Light, electron microscopy and histopathology of Myxobolus salminus n. sp., a parasite of Salminus brasiliensis from the Brazilian Pantanal. Vet Parasitol 165(1):25-29. https://doi.org/ 10.1016/j.vetpar.2009.07.001

Alvarez-Pellitero P, Palenzuela O, Sitjà-Bobadilla A (2008) Histopathology and cellular response in Enteromyxum leei (Myxozoa) infections of Diplodus puntazzo (Teleostei). Parasitol Int 57(2):110-120. https://doi.org/10.1016/j.parint.2007.09.004
Andrade DR, Godinho AL, Godinho HP, Shimoda E (2004) Biologia reprodutiva da tabarana Salminus hilarii (osteichthyes, characidae) na represa de Três Marias. Rev Bras Cienc Vet 11(3):123-128. https://doi.org/10.4322/rbcv.2014.359

Aragão M (1919) Myxobolus lutzi n. sp. Rev Soc Brasil Ciênc 3:325

Azevedo C, Casal G, Marques D, Silva E, Matos E (2011) Ultrastructure of Myxobolus brycon n. sp. (Phylum Myxozoa), parasite of the Piraputanga fish Brycon hilarii (Teleostei) from Pantanal (Brazil). J Eukaryot Microbiol 58(2):88-93. https://doi.org/10.1111/j.15507408.2010.00525.x

Azevedo RK, Vieira DHMD, Vieira GH, Silva RJ, Matos E, Abdallah VD (2014) Phylogeny, ultrastructure and histopathology of Myxobolus lomi sp. nov., a parasite of Prochilodus lineatus (Valenciennes, 1836) (Characiformes: Prochilodontidae) from the Peixes River, São Paulo State, Brazil. Parasitol Int 63(2):303-307. https://doi.org/10.1016/j.parint.2013.11.008

Barta JR, Martin DS, Liberator PA, Dashkevicz M, Anderson JW, Feighner SD, Elbrecht A, Perkins-Barrow A, Jenkins MC, Danforth HD, Ruff MD, Profous-Juchelka H (1997) Phylogenetic relationships among eight Eimeria species infecting domestic fowl inferred using complete small subunit ribosomal DNA sequences. J Parasitol 83(2):262. https://doi.org/10.2307/3284453

Bonetto A, Pignalberi C (1965) Myxobolus paranensis (Protozoa, Myxosporidea), una nueva especie parasita del "Dorado" (Salminus maxillosus). Physis 25:23-26

Capodifoglio KR, Adriano EA, Milanin T, Silva MR, Maia AA (2016) Morphological, ultrastructural and phylogenetic analyses of Myxobolus hilarii n. sp. (Myxozoa, Myxosporea), a renal parasite of farmed Brycon hilarii in Brazil. Parasitol Int 65(3):184-190. https://doi.org/10.1016/j.parint.2015.12.006

Carriero MM, Adriano EA, Silva MR, Ceccarelli PS, Maia AA (2013) Molecular phylogeny of the Myxobolus and Henneguya genera with several new South American species. PLoS One 8(9):e73713. https://doi.org/10.1371/journal.pone.0073713

Cech G, Molnár K, Székely C (2012) Molecular genetic studies on morphologically indistinguishable Myxobolus spp. infecting cyprinid fishes, with the description of three new species, M. alvarezae sp. nov., $M$. sitjae sp. nov. and M. eirasianus sp. nov. Acta Parasitol 57(4):354-366. https://doi.org/10.2478/s11686-012-0045-2

Diamant A, Whipps CM, Kent ML (2004) A new species of Sphaeromyxa (Myxosporea: Sphaeromyxina: Sphaeromyxidae) in devil firefish, Pterois miles (Scorpaenidae), from the northern Red Sea: morphology, ultrastructure and phylogeny. J Parasitol 90(6): 1434-1442. https://doi.org/10.1645/GE-336R

Eiras JC, Molnár K, YS L (2005) Synopsis of the species of Myxobolus Bütschli, 1882 (Myxozoa: Myxosporea: Myxobolidae). Syst Parasitol 61(1):1-46. https://doi.org/10.1007/s11230-004-6343-9

Eiras JC, Zhang J, Molnár K (2014) Synopsis of the species of Myxobolus Bütschli, 1882 (Myxozoa: Myxosporea, Myxobolidae) described between 2005 and 2013. Syst Parasitol 88(1):11-36. https://doi. org/10.1007/s11230-014-9484-5

Eszterbauer E (2004) Genetic relationship among gill-infecting Myxobolus species (Myxosporea) of cyprinids: molecular evidence of importance of tissue-specificity. Dis Aquat Org 58(1):35-40. https://doi.org/10.3354/dao058035

Feist SW, Longshaw M (2006) Phylum Myxozoa. In: Woo PTK (ed) Fish diseases and disorders. Protozoan and metazoan infections, 2nd edn. CAB International, Oxfordshire, pp 230-296

Fiala I (2006) The phylogeny of Myxosporea (Myxozoa) based on small subunit ribosomal RNA gene analysis. Int J Parasitol 36(14):15211534. https://doi.org/10.1016/j.ijpara.2006.06.016

Fiala I, Bartošová-Sojková P, Whipps CM (2015) Classification and phylogenetics of Myxozoa. In: Okamura B (ed) Myxozoan evolution, ecology and development. Springer International Publishing, Switzerland, pp 85-110 
Godoy MP (1975) Peixes do Brasil: Subordem Characoidei: Bacia do Mogi Guassu. Franciscana, Piracicaba

Gómez D, Bartholomew J, Sunyer JO (2014) Biology and mucosal immunity to myxozoans. Dev Comp Immunol 43(2):243-256. https:// doi.org/10.1016/j.dci.2013.08.014

Grankoto A, Pampoulie C, Marques A, Sakiti GN (2001) Myxobolus dahomeyensis infection in ovaries of Tilapia species from Benin (West Africa). J Fish Biol 58(3):883-886. https://doi.org/10.1111/j. 1095-8649.2001.tb00539.x

Guindon S, Dufayard JF, Lefort V, Anisimova M, Hordijk W, Gascuel O (2010) New algorithms and methods to estimate maximumlikelihood phylogenies: assessing the performance of PhyML 3.0. Syst Biol 59(3):307-321. https://doi.org/10.1093/sysbio/syq010

Hall T (2011) BioEdit: an important software for molecular biology. GERF Bull Biosci 2(1):60-61

Hallett SL, Diamant A (2001) Ultrastructure and small-subunit ribosomal DNA sequence of Henneguy a lesteri n.sp. (Myxosporea), a parasite of sand whiting Sillago analis (Sillaginidae) from the coast of Queensland, Australia. Dis Aquat Org 46:197-212. https://doi.org/ 10.3354/dao046197

Kato E, Kasai A, Tomochi H, Li Y, Sato H (2017) Four Myxobolus spp. (Myxosporea: Bivalvulida) from the gill lamellae of common carp (Cyprinus carpio) and Japanese silver crucian carp (Carassius langsdorfii) in the western part of Japan, with the description of three new species (M. tanakai n. sp., M. paratoyamai n. sp., and M. ginbuna n. sp.). Parasitol Res 116(9):2427-2441. https://doi.org/ 10.1007/s00436-017-5545-4

Kearse M, Moir R, Wilson A, Stones-Havas S, Cheung M, Sturrock S, Buxton S, Cooper A, Markowitz S, Duran C, Thierer T, Ashton B, Meintjes P, Drummond A (2012) Geneious Basic: an integrated and extendable desktop software platform for the organization and analysis of sequence data. Bioinformatics 28(12):1647-1649. https:// doi.org/10.1093/bioinformatics/bts199

Kent ML, Khattra J, Hervio DML, Devlin RH (1998) Ribosomal DNA sequence analysis of isolates of the PKX Myxosporean and their relationship to members of the genus. J Aquat Anim Health 10(1): $12-21$

Larkin MA, Blackshields G, Brown NP, Chenna R, McGettigan PA, McWilliam H, Valentin F, Wallace IM, Wilm A, Lopez R, Thompson JD, Gibson TJ, Higgins DG (2007) Clustal W and Clustal X version 2.0. Bioinformatics 23(21):2947-2948. https:// doi.org/10.1093/bioinformatics/btm404

Lom J, Arthur JR (1989) A guideline for the preparation of species descriptions in Myxosporea. J Fish Dis 12(2):151-156. https://doi.org/ 10.1111/j.1365-2761.1989.tb00287.x

Lom J, Dykova I (2006) Myxozoan genera: definition and notes on taxonomy, life-cycle terminology and pathogenic species. Folia Parasitol 53(1):1-36

Longshaw M, Frear P, Feist SW (2003) Myxobolus buckei sp. n.(Myxozoa), a new pathogenic parasite from the spinal column of three cyprinid fishes from the United Kingdom. Folia Parasitol 50(4):251-262

Milanin T, Eiras JC, Arana S, Maia AA, Alves AL, Silva MR, Carriero MM, Ceccareli PS, Adriano EA (2010) Phylogeny, ultrastructure, histopathology and prevalence of Myxobolus oliveirai sp. nov., a parasite of Brycon hilarii (Characidae) in the Pantanal wetland, Brazil. Mem Inst Oswaldo Cruz 105(6):762-769. https://doi.org/ 10.1590/S0074-02762010000600006

Molnár K (1994) Comments on the host, organ and tissue specificity of fish myxosporeans and on the types of their intrapiscine development. Parasitol Hung 27:5-20

Molnár K, Békési L (1993) Description of a new Myxobolus species, M. colossomatis n. sp. from the teleost Colossoma macropomum of the Amazon River basin. J Appl Ichthyol 9(1):57-63. https:// doi.org/10.1111/j.1439-0426.1993.tb00388.x
Molnár K, Ranzani-Paiva MJ, Eiras JC, Rodrigues EL (1998) Myxobolus macroplasmodialis sp. n. (Myxozoa: Myxosporea), a parasite of the abdominal cavity of the characid teleost, Salminus maxillosus, in Brazil. Acta Protozool 37:241-245

Moran JDW, Whitaker DJ, Kent ML (1999) A review of the myxosporean genus Kudoa Meglitsch, 1947, and its impact on the international aquaculture industry and commercial fisheries. Aquaculture 172(1):163-196. https://doi.org/10.1016/S00448486(98)00437-2

Morsy K, Abdel-Ghaffar F, Bashtar AR, Mehlhorn H, Al Quraishy S, Abdel-Gaber R (2012) Morphology and small subunit ribosomal DNA sequence of Henneguya suprabranchiae (Myxozoa), a parasite of the catfish Clarias gariepinus (Clariidae) from the River Nile, Egypt. Parasitol Res 111(4):1423-1435. https://doi.org/10.1007/ s00436-012-2976-9

Naldoni J, Arana S, Maia AAM, Ceccarelli PS, Tavares LER, Borges FA, Pozo CF, Adriano EA (2009) Henneguya pseudoplatystoma n. sp. causing reduction in epithelial area of gills in the farmed pintado, a South American catfish: histopathology and ultrastructure. Vet Parasitol 166(1):52-59. https://doi.org/10.1016/j.vetpar.2009.07. 034

Naldoni J, Zatti SA, Capodifoglio KR, Milanin T, Maia AA, Silva MR, Adriano EA (2015) Host-parasite and phylogenetic relationships of Myxobolus filamentum sp. n. (Myxozoa: Myxosporea), a parasite of Brycon orthotaenia (Characiformes: Bryconidae) in Brazil. Folia Parasitol 62:014. 10.14411/fp.2015.014

Obiekezie AI, Okaeme AN (1990) Myxosporea (Protozoa) infections of cultured tilapias in Nigeria. J Afr Zool 104:77-91. https://doi.org/10. 1111/j.1550-7408.1985.tb03038.x

Okaeme AN, Obiekeziz AI, Lehman J, Antai EE, Madu CT (1988) Parasites and diseases of cultured fish of Lake Kainji area Nigeria. J Fish Biol 32:479-481. https://doi.org/10.1111/j.1095-8649.1988. tb05383.x

Okamura B, Gruhl A, Reft AJ (2015) Myxozoan evolution, ecology and development. Springer International Publishing, Cham

Palenzuela O (2006) Myxozoan infections in Mediterranean mariculture. Parasitology 48(1-2):27-29

Posada D (2008) jModelTest: phylogenetic model averaging. Mol Biol Evol 25:1253-1256. https://doi.org/10.1093/molbev/msn083

Rambaut A (2012) FigTree v1. 4. Molecular evolution, phylogenetics and epidemiology. http://ree.bio.ed.ac.uk/software/figtree/. Accessed 26 Apr 2017

Rambaut A, Suchard M, Xie W, Drummond A (2014) Tracer v. 1.6. http:// tree.bio.ed.ac.uk/software/tracer/. Accessed 26 Apr 2017

Rocha E, Matos E, Azevedo C (1992) Henneguya amazonica n. sp. (Myxozoa, Myxobolidae), parasitizing the gills of Crenicichla lepidota Heckel, 1840 (Teleostei, Cichlidae) from Amazon River. Eur J Protistol 28:273-278. https://doi.org/10.1016/S0932-4739(11) 80233-6

Ronquist F, Huelsenbeck JP (2003) MrBayes 3: Bayesian phylogenetic inference under mixed models. Bioinformatics 19(12):1572-1574

Sitjà-Bobadilla A (2009) Can Myxosporean parasites compromise fish and amphibian reproduction? P R Soc London 276(1669):28612870

Sitjà-Bobadilla A, Alvarez-Pellitero P (1993) Pathologic effects of Sphaerospora dicentrarchi Sitjà-Bobadilla and Alvarez-Pellitero, 1992 and S. testicularis Sitjà-Bobadilla and Alvarez-Pellitero, 1990 (Myxosporea: Bivalvulida) parasitic in the Mediterranean sea bass Dicentrarchus labrax L. (Teleostei: Serranidae) and the cellmediated immune reaction: a light and electron microscopy study. Parasitol Res 79(2):119-129. https://doi.org/10.1007/BF00932257

Swearer SE, Robertson DR (1999) Life history, pathology, and description of Kudoa ovivora n. sp. (Myxozoa, Myxosporea): an ovarian parasite of Caribbean labroid fishes. J Parasitol 85(2):337-353

Tajdari J, Matos E, Mendonca I, Azevedo C (2005) Ultrastructural morphology of Myxobolus testicularis sp. n., parasite of the testis of 
Hemiodopsis microlepis (Teleostei: Hemiodontidae) from the NE of Brazil. Acta Protozool 44(4):377

Torres A, Matos E, Azevedo C (1994) Fine structure of Henneguya amazonica (Myxozoa) in ovarian follicles of Hoplosternum littorale (Teleostei) from the Amazon River. Dis Aquat Org 19:169-172

Ye LT, Li WX, Wang WW, SG W, Wang GT (2014) Updated morphology, histopathology and molecular phylogeny of Myxobolus hearti, cardiac myxosporea in gibel carp, Carassius gibelio (Bloch). J Fish Dis 37(1):11-20. https://doi.org/10.1111/jfd.12026

Yokoyama H, Itoh N, Tanaka S (2005) Henneguya pagri $\mathrm{n}$. sp. (Myxozoa: Myxosporea) causing cardiac henneguyosis in red sea bream, Pagrus major (Temminck \& Schlegel). J Fish Dis 28(8): 479-487. https://doi.org/10.1111/j.1365-2761.2005.00655.x 